\title{
Partha Kar: Leadership without accountability benefits no one
}

\author{
Partha Kar consultant in diabetes and endocrinology \\ Portsmouth Hospitals NHS Trust
}

In the NHS, the term "leadership" generates a huge range of emotions. Sometimes it's ethereal and inspiring. At other times it prompts disdain or even derision. Leadership quangos abound, courses are drip fed into email inboxes, and conferences keep springing up.

Yet every analysis of the NHS's failings tells us the same story-one of a "lack of leadership." Why? Because we don't have the right type of leader? Because we don't have enough "completer-finishers"? Because "leadership" is now seen as a career opportunity? In my view, all of these have contributed to a lack of effective leadership in the NHS.

One thing the NHS should also acknowledge is that the system also needs followers. Many people currently in the NHS seem to believe that we must all be leaders. In promoting the importance and value of leadership the NHS has made being a follower seem far less attractive. You can couch it in any terms you want, but the fact remains that leadership simply isn't for everyone.

In promoting leadership the NHS has made being a follower seem far less attractive

Any leaders worth their salt are only as good as those who follow them. And following isn't unsexy: it's an integral part of making the whole thing work, of delivering care and delivering outcomes.

In other spheres of life, leaders are defined by the outcomes they deliver and by their accountability. In the case of football managers this is often starkly apparent. When José Mourinho was winning trophies, his style was sexy. When the victories dried up, the same man was boorish. Somehow, in the NHS, things rarely work out like that. It's more often a case of old wine in new bottles.

In the NHS, leaders who have failed to deliver in a role are moved from one organisation to another, and organisations are endlessly restructured. But changing the name, structure, or shape of the organisation they led isn't going to deliver outcomes. The problem may lie with the individual rather than the system.

The health service has many challenges, not least around its workforce, structures, and finances. A lack of accountability among leaders-or indeed a lack of those able to deliver beyond the boardroom-may be a significant part of its problems.

The NHS must find a balance between seeing failure as a part of leadership and knowing when to draw the line. We need to know that we shouldn't accept failure as the norm, and we need to know when to find someone else to do the job. In tipping the balance towards allowing failure without accountability, we benefit no one.

Competing interests: I am associate national clinical director for diabetes with NHS England, leading on digital innovation.

Provenance and peer review: Commissioned; not externally peer reviewed.

Published by the BMJ Publishing Group Limited. For permission to use (where not already granted under a licence) please go to http://group.bmj.com/group/rights-licensing/ permissions 